\title{
Cattle Diets in the Blue Mountains of Oregon, I. Grasslands
}

\author{
JERRY L. HOLECHEK, MARTIN VAVRA, JON SKOVLIN, AND WILLIAM C. KRUEGER
}

\begin{abstract}
Esophageally fistulated cows were used to determine cattle diets on grassland range in northeastern Oregon in 1976, 1977, and 1978. Idaho fescue, bluebunch wheatgrass, and Sandberg bluegrass were the most common species in the diets. Forb consumption declined while grass consumption increased with seasonal advance from late spring to fall. Food habits depended largely on phenological development of forage species. Forbs were preferred over grasses early in the grazing season; then after forbs reached maturity, cattle were selective for the plants that remained green. Diet similarities were compared between periods within years, and between years within periods. When diets were pooled into late spring, early summer, late summer and fall groups, late spring diets were least similar to the others. Diet variation from year to year was also less later in the grazing season. Utilization of Idaho fescue and bluebunch wheatgrass should be considered in grazing management decisions on grasslands in the Blue Mountains.
\end{abstract}

Efficient range management depends, in part, on the identification of plants that are palatable and nutritious to livestock. There is

Authors are, respectively, graduate research assistant, associate professor rangeland resources, Oregon State University, Eastern Oregon Agricultural Research Center, Union, Orcgon; professor, project leader, U.S. Dep. Agr. Range and Wildlife Habitat Laboratory, La Grande; and leader, Rangeland Resources Program, Oregon State Univ., Corvallis.

J.L. Holechek is currently assistant professor of range ecology. Department of Animal and Range Sciences, New Mexico State University, Las Cruces 88003 . William C. Krueger is currently professor and head, Department of Range Science, Colorado State University, Fort Collins, Colorado, 80521.

This was submitted as Oregon State Agricultural Experiment Station Technical Paper Number 5402. This research was jointly funded by the Eastern Oregon Agricultural Research Center, Oregon State University and the Pacific Northwest Forest and Range Experiment Station, United States Forest Service, and was part of the PNWFRES Project 1701 entitled, "The influence of cattle grazing methods and big game on riparian vegetation, aquatic habitat and fish populations."

Manuscript received May 9, 1980 growing interest concerning important forage species on mountain rangelands in the northwestern United States because of problems in determining proper stocking rates and allocating forage between livestock and wildlife.

Presently, information involving cattle diets on range in northeastern Oregon and southeastern Washington is limited to utilization studies reported by Pickford and Reid (1948), Harris (1954), and Miller and Krueger (1976). The objectives of this study were to determine important forage species in cattle diets with seasonal advance and among years on grassland range in the Blue Mountains of northeastern Oregon.

\section{Experimental Site and Procedures}

The study area was located on the Starkey Experimental Range near La Grande, Oregon. The area was situated on a gentle southfacing slope above Meadow Creek at an elevation of $1,250 \mathrm{~m}$ above mean sea level (Fig. 1). Precipitation averages $53 \mathrm{~cm}$ and comes primarily in the winter and spring. In about one year out of two, there is sufficient summer precipitation to produce fall regrowth. Precipitation occurring on the study area during 3 years of study is presented in Table 1.

Two 120-ha range units having the same grazing history were established. Vegetation structure of the pastures was nearly identical. Plant species characteristic of the Palouse prairie dominate the pastures (Strickler 1966). Vegetation is representative of the bluebunch wheatgrass-Sandberg bluegrass (Agropyron spicatum-Poa sandbergii) and ponderosa pine-Idaho fescue (Pinus ponderosaFestuca idahoensis) associations as originally described by Daubenmire and Daubenmire (1968) and identified by Ganskopp (1978). These associations occupy 50 and $15 \%$ of each pasture, respectively. A Sandberg bluegrass-bluebunch wheatgrass (Poa 


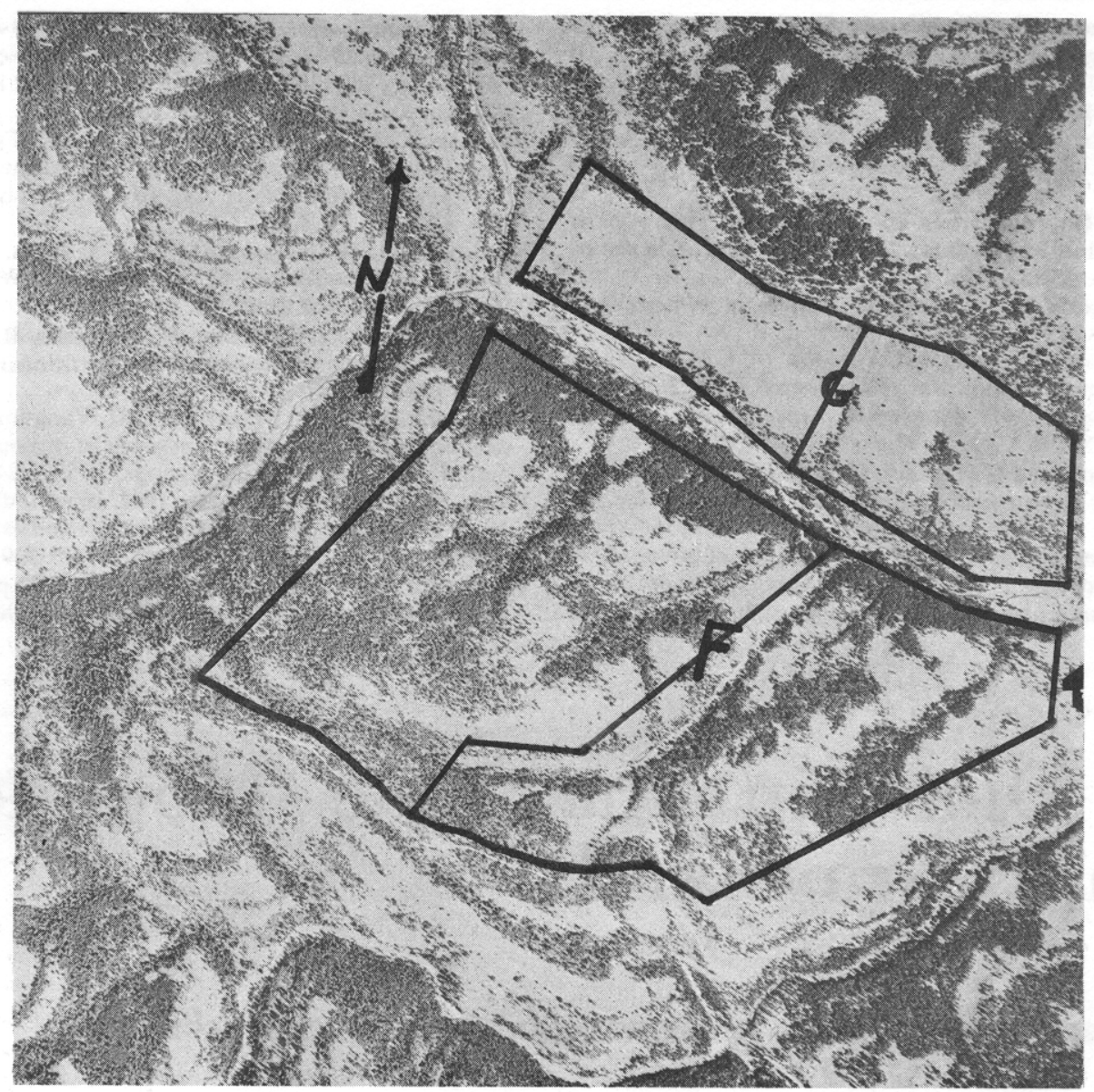

Fig. 1. Aerial photograph of the study area showing forest $(F)$ and grassland $(G)$ pastures outlined in black.

sandbergii-Agropyron spicatum) plant community occupied another $35 \%$ of each pasture. Relative percent cover on the pastures was reported by Ganskopp (1978). Most of the species were perennial in nature; thus, only slight variations were found in species composition among years. Because the vegetation composition of the two pastures was similar, cover data were pooled across pastures (Table 2).

Pastures were enclosed with a four-strand barb wire fence, having a common watering tank between them. Cattle were grazed on the pastures from June 20 to October 10 in 1976, 1977, and 1978 under a two pasture-one herd rest rotation system that involved grazing one pasture season long in 1976 and resting the other pasture. In 1977 grazing was initiated on the pasture rested in 1976. At mid-season cattle were moved to the other pasture. In 1978, the

Table 1. Precipitation (cm) at the Starkey Experimental Range and Forest.

\begin{tabular}{lcccc}
\hline \hline Month & $\begin{array}{c}25 \text { year } \\
\text { Mean }\end{array}$ & 1976 & 1977 & 1978 \\
\hline January & 6.48 & 6.86 & 1.02 & 5.08 \\
February & 4.27 & 2.29 & 2.54 & 4.06 \\
March & 4.57 & 2.54 & 2.11 & 3.56 \\
April & 4.42 & 5.08 & 2.79 & 6.68 \\
May & 5.44 & 4.39 & 4.80 & 4.01 \\
June & 4.72 & 3.71 & 1.83 & 3.12 \\
July & 1.57 & 0.05 & 0.13 & 2.54 \\
August & 2.01 & 6.86 & 7.42 & 3.43 \\
September & 2.72 & 3.71 & 9.42 & 4.11 \\
October & 4.52 & 2.67 & 3.76 & 7.11 \\
November & 5.66 & 4.06 & 7.75 & 4.06 \\
December & 6.68 & 0.00 & 9.40 & 3.20 \\
\cline { 5 - 5 } Total & 53.06 & 42.22 & 52.97 & 50.96 \\
\hline
\end{tabular}

Table 2. Percent cover pooled by pastures of the primary forage species and their contribution by percent weight to cattle diets pooled by grazing periods and years. Pasture cover data are from Ganskopp (1978).

\begin{tabular}{lcc}
\hline \hline Species & $\begin{array}{c}\text { Percent } \\
\text { cover }\end{array}$ & $\begin{array}{c}\text { Percent } \\
\text { in diet }\end{array}$ \\
\hline Bluebunch wheatgrass (Agropyron spicatum) & 25 & 28 \\
Cheatgrass brome (Bromus tectorum) & 1 & 1 \\
Idaho fescue (Festuca idahoensis) & 15 & 29 \\
Prairie junegrass (Koeleria cristata) & 3 & 3 \\
Sandberg bluegrass (Poa sandbergii) & 30 & 8 \\
Western needlegrass (Stipa occidentalis) & 1 & 1 \\
$\quad$ Total grasses & 80 & 80 \\
Western yarrow (Achillea millefolium lanulosa) & 1 & 3 \\
Arrowleaf balsamroot (Balsamorhiza sagittata) & $\mathrm{T}$ & 2 \\
Wyeth eriogonum (Eriogonum heracleoides) & 6 & 2 \\
Lupine (Lupinus spp.) & 1 & 1 \\
Mules ear wyethia (Wyethia amplexicaulis) & $\mathrm{T}$ & 1 \\
$\quad$ Total forbs & 16 & 14 \\
Common snowberry (Symphoricarpos albus) & 4 & 6 \\
$\quad$ Total shrubs & 4 & 6 \\
\hline
\end{tabular}

$\mathrm{T}=$ Trace.

pasture rested in 1976 was grazed while the other pasture was rested all season.

Four esophageally fistulated cows were used to collect diet samples in all 3 years of study. In addition, 18 head of yearling heifers and four fecal collector steers were grazed on the pastures. A moderate rate of stocking was prescribed after criteria developed by Skovlin et al. (1976). Diet quality, forage intake, and livestock performance were given in Holechek et al. (1981). Two collections 
were made every other week with the fistulated animals. Fistulated cows were grazed continuously on the pasture under study in all periods. The sampling scheme involved collecting two samples from each cow on the same week on a biweekly basis. The collection procedure involved hazing the fistulated cows to various parts of the pasture and allowing them to graze freely until at least $1 \mathrm{~kg}$ of grazed forage was acquired. To show trends in diet botanical composition, the grazing season was divided into four 28-day periods which were June 20 to July 18 (late spring), July 19 to August 15 (early summer), August 16 to September 12 (late summer), and September 13 to October 10 (fall). A total of 16 samples was collected for each period.

The microhistological technique of Sparks and Malechek (1968) was used in botanical analysis of diet samples. Sixty microscope fields were examined at $100 \times$ for each sample.

Differences in consumption of individual species among periods and years were determined using analysis of variance (Steel and Torrie 1960). Similarity indexes (Oosting 1956) as applied to diet analysis (Olsen and Hansen 1977) were used to evaluate the repeatibility of diet constituents between periods within years and within periods between years.

\section{Results and Discussion}

During the 3 years of study, 18 grass species, 26 species of forbs and 4 shrubby species were found in cattle diet samples. Diet botanical composition was diverse in the late spring when nearly all the plants were green. However only a few species were consumed after the forage reached maturity. Springfield and Reynolds (1951) and Beck (1975) reported that cattle selected a wide range of forage species when plants were young and growing, but only a few species were selected after forage reached maturity.

When samples were pooled across years and periods, bluebunch wheat grass $^{1}$ and Idaho fescue comprised $57 \%$ of the diet (Table 2). Idaho fescue was less abundant than bluebunch wheatgrass but was more preferred on the basis of $\%$ by weight consumed to relative cover on the pasture. However, because standing crop data were not collected, a quantitative preference value was not assigned. Sandberg bluegrass was the most common species on the pastures (Table 2) but comprised only $8 \%$ of the diet. Pickford and Reid (1948) and Uresk and Richard (1976) reported cattle had a low preference for Sandberg bluegrass. Other grasses contributing at least $1 \%$ of cattle diets pooled across periods and years, included prairie Junegrass, western needlegrass, and cheatgrass brome.

IScientific names of plants are given in Table 2 and follow Garrions and Skovlin (1976).
Western yarrow was the most important forb in diets and the only one comprising $1 \%$ or more of cattle diets in the latter half of the grazing season during 3 years of study. This forb species remains green after most of the other forbs have matured. Pickford and Reid (1948) reported western yarrow was used throughout the grazing season on the Starkey Range and was a preferred species.

Arrowleaf balsamroot occurred erratically in cattle diets early in the grazing season. It comprised less than $1 \%$ of the plant cover and was found in rocky parts of the pasture that had received light use in the past. In late spring cattle sometimes consumed an entire plant but by maturity it was ignored. Pickford and Reid (1948) also reported that arrowleaf balsamroot was one of the most palatable plants on the Starkey Range when it was green.

Wyeth eriogonum was the most common forb on the pastures but received relatively little use because its low growth form and woody nature caused it to be unavailable and unpalatable. Several species of lupine and mules ear wyethia were important in cattle diets during particular collections. However, they never comprised more than $2 \%$ of the diet when samples were pooled across years and periods. Availability probably limited their consumption.

Common snowberry was the only shrub occurring in cattle diets in more than trace amounts because it was found only on small areas occupied by ponderosa pine. Cattle used snowberry throughout the grazing season when they encountered it, but they usually grazed parts of the pastures where it was unavailable.

During all 3 years, cattle diets shifted toward more grass and fewer forbs as the grazing season advanced (Table 3). This is probably explained by reduced forb palatability with phenological advancement. Pickford and Reid (1948) reported similar trends in grass and forb consumption on the Starkey range.

Grass consumption ranged from a low of $54 \%$ in late spring, 1978, to $91 \%$ in fall, 1977. Other investigators have reported grasses to be the most important component of cattle diets (Cook et al. 1963, Van Dyne and Heady 1965, Galt et al. 1969; Cook et al. 1967, Beck 1975). In this study, when they were green, forbs were highly preferred relative to grasses. Vavra (1972) reported cattle preferred forbs over grasses on shortgrass range during early stages of phenological development.

Cattle diets were significantly lower $(P<.05)$ in forbs in 1977 than in the other 2 years. The spring and early summer of 1977 were drier than 1976 or 1978 (Table 1) and many forb species approached maturity when cattle grazing was initiated. Advanced phenology explains the relatively low consumption of forbs during the first half of 1977 compared to the other 2 years.

Although forbs were more important in cattle diets in 1978 than in 1976 or 1977 , fewer forb species were found in diet samples in

Table 3. The percent by weight of important species found in cattle diets in 1976, 1977, and 1978.

\begin{tabular}{|c|c|c|c|c|c|c|c|c|c|c|c|c|}
\hline \multirow[b]{2}{*}{ Species } & \multicolumn{4}{|c|}{1976} & \multicolumn{4}{|c|}{1977} & \multicolumn{4}{|c|}{1978} \\
\hline & $\begin{array}{l}\text { Late } \\
\text { spring }\end{array}$ & $\begin{array}{l}\text { Early } \\
\text { sum- } \\
\text { mer }\end{array}$ & $\begin{array}{l}\text { Late } \\
\text { sum- } \\
\text { mer }\end{array}$ & Fall & $\begin{array}{l}\text { Late } \\
\text { spring }\end{array}$ & $\begin{array}{l}\text { Early } \\
\text { sum- } \\
\text { mer }\end{array}$ & $\begin{array}{l}\text { Late } \\
\text { sum- } \\
\text { mer }\end{array}$ & Fall & $\begin{array}{l}\text { Late } \\
\text { spring }\end{array}$ & $\begin{array}{l}\text { Early } \\
\text { sum- } \\
\text { mer }\end{array}$ & $\begin{array}{l}\text { Late } \\
\text { sum- } \\
\text { mer }\end{array}$ & Fall \\
\hline Bluebunch wheatgrass & $16^{b}$ & $28^{n}$ & $34^{n}$ & $36^{\prime \prime}$ & $28^{\mathrm{b}}$ & $33^{\mathbf{a b}}$ & $38^{*}$ & $39^{n}$ & $15^{b}$ & $18^{b}$ & $22^{\mathrm{ab}}$ & $28^{a}$ \\
\hline Cheatgrass brome & 1 & $\mathbf{T}$ & - & - & & & & & 1 & 2 & 3 & 5 \\
\hline Idaho fescue & $18^{b}$ & $36^{\circ}$ & $38^{a}$ & $34^{a}$ & $41^{\mathrm{a}}$ & $34^{b}$ & $32^{b}$ & $23^{\mathrm{c}}$ & $11^{\mathrm{b}}$ & $26^{\mathrm{a}}$ & $33^{*}$ & $28^{a}$ \\
\hline Prairie junegrass & 3 & 4 & 3 & 4 & 2 & 1 & 2 & 4 & 2 & 1 & 1 & 7 \\
\hline Sandberg bluegrass & 2 & 5 & 3 & 1 & 2 & 2 & 5 & 12 & 8 & 16 & 15 & 14 \\
\hline Western needlegrass & 5 & 2 & 4 & 3 & & & & & & & & \\
\hline Total grasses & $64^{b}$ & $86^{a}$ & $90^{\circ}$ & $85^{\circ}$ & $78^{b}$ & $79^{b}$ & $90^{\circ}$ & $91^{2}$ & $54^{c}$ & $70^{b}$ & $90^{\circ}$ & $89^{\circ}$ \\
\hline Western yarrow & 5 & 1 & 4 & 3 & 3 & 3 & 1 & 1 & $10^{\circ}$ & $\mathbf{b}^{\mathbf{b}}$ & $2^{b}$ & $1^{b}$ \\
\hline Arrowleaf balsamroot & 3 & $\mathbf{T}$ & $\mathbf{T}$ & - & 2 & 2 & - & $\mathrm{T}$ & 10 & $\mathbf{T}$ & - & $\mathrm{T}$ \\
\hline Wyeth eriogonum & $\mathbf{T}$ & $\mathrm{T}$ & $\mathrm{T}$ & $\mathbf{T}$ & 3 & 4 & 1 & $\mathbf{T}$ & & & & \\
\hline Lupine & 4 & $\mathbf{T}$ & $\mathrm{T}$ & - & & & & & 4 & 5 & - & - \\
\hline Mules ear wyethia & & & & & & & & & 3 & 2 & $\mathbf{T}$ & $\mathbf{T}$ \\
\hline Total forbs & $28^{n}$ & $8^{b}$ & $t^{b}$ & $t^{b}$ & 16 & 14 & 5 & 4 & $41^{*}$ & $25^{\mathrm{b}}$ & $4^{c}$ & $5^{c}$ \\
\hline Common snowberry & 7 & 4 & 4 & 7 & 5 & 4 & 4 & 4 & 3 & 4 & 5 & 5 \\
\hline Total shrubs & 8 & 6 & 3 & 8 & 6 & 7 & 5 & 5 & 5 & 5 & 6 & 6 \\
\hline
\end{tabular}

a,b,e Means with different superscripts within the same row and year are significantly different at the .05 level. 
1978. Vavra (1972) reported fewer forb species in cattle diets in a year when growing season precipitation was above average. He attributed this to higher availability of the preferred species.

The mid-season movement of cattle in 1977 resulted in little change in diets. Forb consumption was actually lower after the move which further suggests that the reduction in forb consumption in early summer during the 3 years was the result of advanced phenological development.

Grazing pressure was lighter in 1977 than in 1976 or 1978 because cattle grazed both grassland pastures rather than one. However, cattle diets were similar in the latter half of the grazing season in all 3 years.

Idaho fescue had more green leaves than other grasses in the summer and it was preferred. In the latter part of the grazing season, cattle purposely sought Idaho fescue plants which had received heavy grazing pressure earlier in the season because regrowth was more available on these plants. Beck (1975) reported that plant phenological development was the primary factor influencing cattle diet selection in southeastern Colorado.

The erratic consumption of Sandberg bluegrass in different periods and years is explained by phenological development. In 1976 and 1977 this species had already approached maturity when grazing was initiated. However, heavy rainfall occurred during the summer of 1977 and Sandberg bluegrass showed considerable regrowth in the fall. Significantly more $(P<.05)$ of this species was used in the fall than during the late spring or summer. Pickford and Reid (1948) reported increased utilization of Sandberg bluegrass after late summer rainfall. In 1978 Sandberg bluegrass remained green much longer and significantly more $(P<.05)$ was found in diets.

Similarity indexes comparing diets among the four different periods (Table 4) revealed that diets in late spring were the least similar in 1976 and 1978. Late spring grazing occurred when availability was greatest and all forage species were green and immature. There was less forage available for selection later in the season as grazing removed some forage and maturity made other species less palatable and hence larger similarity values were observed. As expected, the drought year of 1977 did not follow the same trend. Diets were similar summer long due to limited availability.

Table 4. The percent similarity of cattle diets comparing grazing periods, within years.

\begin{tabular}{lccc}
\hline & \multicolumn{3}{c}{ Year } \\
\cline { 2 - 4 } Period comparison & 1976 & 1977 & 1978 \\
\hline LS-ESul & 46 & 78 & 59 \\
LS-LSu & 51 & 71 & 48 \\
LS-F & 51 & 61 & 49 \\
ESu-LSu & 76 & 75 & 68 \\
ESu-F & 74 & 65 & 66 \\
LSu-F & 82 & 74 & 74 \\
\hline
\end{tabular}

' $L S=$ late spring, $E S u=$ early summer, $L S u$ - late summer, $F=$ fall.

When similarity indexes were calculated, comparing individual periods among years, the same trends were evident (Table 5). Diets in the late spring period when availability was greatest were the least similar among years. Late summer and fall diets were quite similar, indicating that differences in selection due to differences in annual forage availability are more pronounced during the early stages of the grazing season.

\section{Conclusions}

In late spring when availability was greatest, cattle diets were the most diverse. As the grazing season progressed, fewer plant species were consumed and the more repeatable diets became among periods and years. Idaho fescue and bluebunch wheatgrass were the most important diet constituents. Most of the similarity in diets among years and periods can be attributed to the amounts of Idaho fescue and bluebunch wheatgrass in the diet. Cover data indicate that Idaho fescue was more limited on the pastures than was
Table 5. The percent similarity of cattle diets comparing years within each grazing period.

\begin{tabular}{lcccc}
\hline \hline & \multicolumn{4}{c}{ Grazing Period } \\
\cline { 2 - 5 } Year & $\begin{array}{c}\text { Late } \\
\text { Somparison }\end{array}$ & $\begin{array}{c}\text { Early } \\
\text { summer }\end{array}$ & $\begin{array}{c}\text { Late } \\
\text { summer }\end{array}$ & Fall \\
\hline $1976-1977$ & 48 & 70 & 76 & 72 \\
$1976-1978$ & 46 & 45 & 66 & 67 \\
$1977-1978$ & 38 & 44 & 65 & 72 \\
\hline
\end{tabular}

bluebunch wheatgrass and therefore the most preferred forage species. However, both Idaho fescue and bluebunch wheatgrass should be considered in grazing management decisions on mountain grasslands. Forbs were important diet constituents particularly early in the grazing season. When allocating forage to wildlife and livestock, forb use by cattle should be considered. During drought years increased use of important grass species can be expected early in the grazing season and management should be incorporated to prevent overgrazing of key species.

\section{Literature Cited}

Beck, Reldon. 1975. Steer diets in southeastern Colorado. J. Range Manage. 28:48-52.

Cook, C.W., J.T. Blake, and J.W. Call. 1963. Use of esophageal fistula cannulae for collecting forage samples from both sheep and cattle grazing in common. J. Anim. Sci. 22:579-581.

Cook, C.W., L.E. Harris, and C.M. Young. 1967. Botanical and nutritive content of diets of cattle and sheep under single and common use on mountain range. J. Anim. Sci. 26:1169-1174.

Daubenmire, R. and J.B. Daubenmire. 1968. Forest vegetation of eastern Washington and northern Idaho. Wash. Agr. Exp. Sta. Pullman, Tech. Bull. $60.104 \mathrm{p}$.

Galt, H.D.B., J.H. Theurer, J.H. Ehrenreich, W.H. Hale, and S.C. Martin. 1969. Botanical composition of diet of steers grazing a desert grassland range. J. Range Manage. 22:14-17.

Garrison, G.A., and J.M. Skovlin. 1976. Plant names and symbols for ecosystem inventory analysis. Pacific Northwest. Forest and Range Exp. Sta. Forest Serv. U.S. Dep. Agr. Gen. Tech. Rep. PNW-46. 263 p.

Ganskopp, David Conrad. 1978. Plant communities and habitat types of the Meadow Creek experimental watershed. M.S. Thesis. Oregon State Univ., Corvallis.

Harris, Robert W. 1954. Fluctuations in forage utilization on ponderosa pine ranges in eastern Oregon. J. Range Manage. 7:250-255.

Holechek, J.L., M. Vavra, J.M. Skovlin, and R.L. Phillips. 1980. Diet quality, intake and performance of yearling heifers on grassland and forested range. J. Anim. Sci. 53:291-298.

Miller, Richard F., and William C. Krueger. 1976. Cattle use on summer foothill rangelands in northeastern Oregon. J. Range Manage. 29:367371

Olsen, Frank W, and Richard M. Hansen. 1977. Food relations of wild free-roaming horses to livestock and big game, Red Desert, Wyoming. J. Range Manage. 30:17-20.

Oosting, H.J. 1956. The study of plant communties. W.H. Freeman and Company, San Francisco. 440 p.

Pickford, G.D., and E.H. Reid. 1948. Forage utilization on summer cattle ranges in eastern Oregon. U.S. Dep. Agr. Circular 796. 27 p.

Skovlin, J.M., R.W. Harris, G.S. Strickler, and G.A. Garrison. 1976. Effects of cattle grazing methods on ponderosa pine-bunchgrass range in the Pacific Northwest. U.S. Dep. Agr. Tech. Bull. 1531. 40 p.

Sparks, D.R., and J.C. Malechek. 1968. Estimating percentage dry weight in diets using a microscopic technique. J. Range Manage. 21:264-265.

Springfield, H.W., and H.G. Reynolds. 1951. Grazing preferences of cattle for certain reseeding grasses. J. Range Manage. 4:83-87.

Steel, R.G., and J.H. Torrie. 1960. Principles and Procedures of Statistics. McGraw-Hill Book Co., Inc. New York. 481 p.

Strickler, Gerald S. 1966. Soil and vegetation on the Starkey Experimental Forest and Range. Soc. Amer. Forest Proc. 1965:27-30.

Uresk, Daniel W., and W.H. Richard. 1976. Diets of steers on shrub-steppe rangeland in south-central Washington. J. Range Manage. 29:464-467.

Van Dyne, G.M., and H.F. Heady. 1965. Botanical composition of sheep and cattle diets on a mature annual range. Hilgardia. 36:465-470.

Vavra, Martin. 1972. Diet and intake of yearling cattle on different grazing intensities of shortgrass range. Ph.D. Thesis. Univ. of Wyoming, Laramie. $126 \mathrm{p}$. 